\title{
Perforin-dependent nuclear entry of granzyme B precedes apoptosis, and is not a consequence of nuclear membrane dysfunction
}

\author{
Joseph A. Trapani ${ }^{1,5}$, Patricia Jans ${ }^{2}$, Mark J. Smyth ${ }^{1}$, \\ Christopher J. Froelich ${ }^{3}$, Elizabeth A. Williams ${ }^{4}$, \\ Vivien R. Sutton ${ }^{1}$ and David A. Jans ${ }^{2,5}$ \\ ${ }^{1}$ Cellular Cytotoxicity Laboratory, The Austin Research Institute, Studley Road, \\ Heidelberg, 3084, Australia \\ 2 Nuclear Signalling Laboratory, Division for Biochemistry and Molecular \\ Biology, John Curtin School of Medical Research, Canberra City, 2601, \\ Australia \\ ${ }^{3}$ Department of Medicine, Northwestern University Medical School, Evanston \\ Illinois, USA \\ ${ }^{4}$ Centre for Applied Cancer Studies, University of Western Australia \\ ${ }^{5}$ corresponding authors: Dr. Joseph A. Trapani, Cellular Cytotoxicity \\ Laboratory, The Austin Research Institute, Studley Road, Heidelberg, 3084, \\ Australia; tel: 61-3-92870651; fax: 61-3-9287-0600; e-mail: ja-trapani @- \\ muwayf.unimelb.edu.au, and Dr. David A. Jans, Nuclear Signalling Laboratory, \\ Division for Biochemistry and Molecular Biology, John Curtin School of \\ Medical Research, Australian National University, P.0. Box 334, Canberra City, \\ A.C.T. 2601, Australia; tel: 61-6-249-4188; fax: 61-6-249-0415; e-mail: \\ daj224@leonard.anu.edu.au
}

Received 5.10.97; revised 28.12.97; accepted 19.1.98

Edited by A.H. Greenberg

\begin{abstract}
Killer lymphocytes utilize the synergy of a membranolytic protein, perforin, and the serine protease granzyme $B$ (grB) to induce target cell apoptosis, however the mechanism of this synergy remains incompletely defined. We have previously shown that perforin specifically induces the redistribution of cytoplasmic grB into the nucleus of dying cells, however a causal role for nuclear targeting of grB in cell death has not been demonstrated. In the present study, we used confocal laser scanning microscopy (CLSM) to determine whether the nuclear accumulation of fluoresceinated (FITC-) grB precedes or is a consequence of apoptosis. Two distinct and mutually exclusive cellular responses were observed in FDC-P1 cells: (i) up to $50 \%$ of the cells rapidly accumulated FITC-grB in the nucleus (maximal at $7 \mathrm{~min} ; \mathrm{t}_{1 / 2}$ of $2 \mathrm{~min}$ ) and underwent apoptosis; (ii) the remaining cells took up FITC-grB only into the cytoplasm, and escaped apoptosis. Under these conditions, DNA fragmentation was not observed for at least $13 \mathrm{~min}$, indicating nuclear accumulation of grB preceded the execution phase of apoptosis. Furthermore, nuclear import of grB proceeded through an intact nuclear membrane, as the nuclei of cells whose cytoplasm was pre-loaded with $70 \mathrm{kDa}$ FITC-dextran excluded dextran for up to $90 \mathrm{~min}$ while still undergoing apoptosis in response to perforin and grB. These findings indicated that perforin-induced nuclear accumulation of grB precedes apoptosis, and is not a by-product of caspase-induced nuclear membrane degradation. The cell
\end{abstract}

membrane lesions formed by perforin in these experiments were not large enough to permit a $13 \mathrm{kDa}$ protein (yeast cdk p13 ${ }^{\text {suc }}$ ) access into the cytoplasm, but an $8 \mathrm{kDa}$ protein (bacterial azurin) was able to equilibrate between the cytosol and the exterior. Therefore, transmembrane pores large enough to allow passive diffusion of $\mathrm{grB}(32 \mathrm{kDa})$ into the cell are not necessary for apoptosis. Rather, a perforindependent signal results in a redistribution of grB from the cytoplasm to the nucleus, where it may contribute to the nuclear changes associated with apoptosis.

Keywords: granzyme; perforin; caspases; nuclear localization; cytolytic lymphocyte

Abbreviations: grB, granzyme $\mathrm{B}$; ICE, interleukin- $1 \beta$-converting enzyme; PARP, poly(ADP-ribose) polymerase; DNA-PKcs, catalytic subunit of DNA dependent protein kinase; CLSM, confocal laser scanning microscopy.

\section{Introduction}

Killer cells such as CTL utilize two principal means of inducing an apoptotic signal in target cells. The first involves engagement of the receptor molecule, Fas/CD95 on the target cell by its ligand CD95L/FasL on the effector (Rouvier et al, 1993; Yonehara et al, 1989; Trauth et al, 1989). The second involves exocytosis of the contents of cytoplasmic granules from the killer cell toward the target (Young and Cohn, 1986; Smyth and Trapani, 1995). The apoptotic effects of cytolytic granules can be mimicked by exposing cells to just two molecules, the pore-forming protein perforin, and the serine protease granzyme B (grB) (Shi et al, 1992). Neither perforin nor grB is able to induce apoptosis in the absence of the other agent (Shi et al, 1992; Duke et al, 1989). Accordingly, perforin-deficient mice exhibit defective cytolysis against virus-infected, allogeneic and tumor targets (Kagi et al, 1994; Lowin et al, 1994), and the killer lymphocytes of mice lacking grB induce delayed cell death (Heusel et al, 1994).

There has been a great deal of recent interest in the mechanism of grB/perforin synergy, but even the precise sites of action of the two molecules are yet to be agreed. Perforin, a membranolytic agent, inserts in the target cell membrane (Ortaldo et al, 1992) and is not known to enter the cytoplasm. Cells whose cytoplasm is preloaded with certain protease inhibitors may withstand CTL attack (Nakajima and Henkart, 1994) through the inhibition of apoptotic cysteine proteases similar to the Caenorhabditis elegans protein, CED-3 (Sarin et al, 1997). GrB cleaves at specific aspartic acid residues (Poe et al, 1991), and its 
substrates include interleukin-1 $\beta$-converting enzyme (ICE) and multiple other apoptotic cysteine proteases. These include proteases both near the apex of the cascade (Mch5/Mch1a/FLICE and Mch4; Boldin et al, 1995, 1996; Fernandex-Alnemri et al, 1996), and CPP32 (Caspase 3) (Fernandes-Alnemri et al, 1996; Darmon et al, 1995; Quan et al, 1996), which is further downstream. Activated CPP32 plays a key role in DNA fragmentation (Darmon et al, 1996) by inactivating poly(ADP-ribose) polymerase (PARP ${ }^{1}$ ) (Lazebnik et al, 1994; Nicholson et al, 1995; Tewari et al, 1995; Fernandes-Alnemri et al, 1996) and the catalytic subunit of DNA-dependent protein kinase (DNA-PKcs) (Song et al, 1996; Kaufmann et al, 1993). Direct activation of Mch2a by grB also results in the cleavage of structural nucleoproteins such as lamins (Srinivasula et al, 1996). Recent evidence suggests grB may also directly cleave PARP (Froelich et al, 1996a) and DNA-PKcs (Song et al, 1996) at sites distinct from those of the CED-3-like proteases. Thus, both grB and the caspases may be capable of contributing to nuclear apoptotic morphology.

We (Trapani et al, 1996; Jans et al, 1996; Shi et al, 1997) and others (Pinkowski et al, 1996) have demonstrated the capacity of grB to localize within the cytoplasm of target cells independently of perforin, indicating that perforin-induced pore-formation does not adequately explain the cellular uptake of apoptotic proteases such as grB. Nevertheless, cells that have taken up grB remain indefinitely viable in the absence of perforin. The coaddition of perforin induces apoptosis, and this is accompanied by a pronounced redistribution of grB from the cytoplasm to the nucleus of the dying cell (Trapani et al, 1996; Shi et al, 1997). Perforin may therefore play a key role in 'redeploying' grB from some shelted compartment such as an edosome [as was postulated recently by Froelich et al (1996a)] to the cytosol, where it might now access its substrates in both the cytoplasm and nucleus. Despite the appeal of this hypothesis, a causal relationship between nuclear accumulation and apoptosis has not been established. It is possible that entry of grB into the nucleus is not a primary event, rather a mere consequence of prior nuclear membrane damage, perhaps as a result of the immediate activation of the caspase cascade. To address these issues, we performed a careful quantitative and kinetic analysis of grB's intracellular distribution during apoptosis, using confocal laser-scanning microscopy (CLSM). Our results clearly demonstrate that perforininduced redistribution of grB to the nucleus precedes, and is invariably followed by nuclear apoptotic changes eventually culminating in cell death. These observations are consistent with the notion that in addition to activating key cytoplasmic pathways, grB may contribute directly to the distinctive nuclear changes of apoptotic cell death.

\section{Results}

\section{Sublytic concentrations of perforin induce nuclear uptake of $\mathbf{g r B}$}

FDC-P1 cells were exposed to perforin and FITC-grB and observed by CLSM (Figure 1A). Two populations of cells became evident within 2-4 min: in about $50 \%$ of the cells, the cytoplasm and nucleus became fluorescent, and this staining was predictive of ensuing apoptotic death. The remainder of the cells also took up grB, but in lower amounts, and appeared to be spared from apoptosis. In the stronger stained population, grB was localized principally within the nucleus as compared to the cytoplasm (Figure $1 \mathrm{~A}$ right panel). At early time points ( $<20 \mathrm{~min}$ ), neither population showed apoptotic features: the outline of the nucleus was smooth and regular, and fluorescence was distributed uniformly throughout all of the nuclei (Figure 1).

A

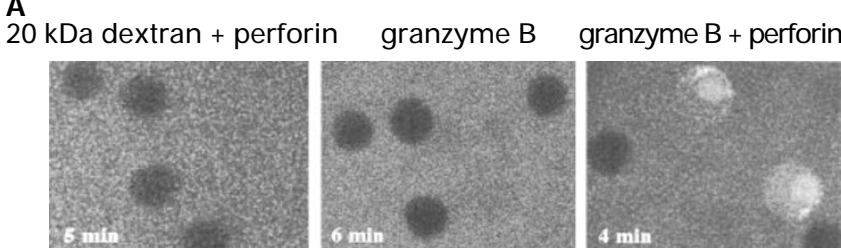

B

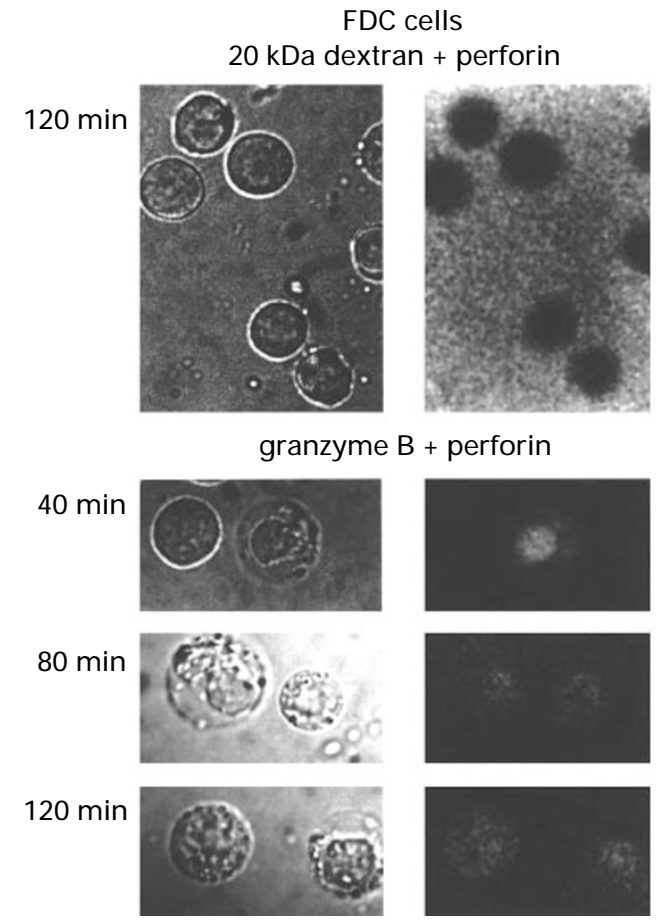

Figure 1 (A) Uptake and nuclear accumulation of FITC-grB by FDC-P1 cells is dependent on perforin. Cells were exposed to either FITC-dextran $(20 \mathrm{kDa})$ in the presence of perforin (left), or FITC-grB in the absence (centre) or presence (right) of perforin at $37^{\circ} \mathrm{C}$, and fluorescence visualized at the times indicated using CLSM. The experiment depicted was typical of 12 similar experiments performed over a range of grB concentrations $(0.5$ to $10 \mu \mathrm{g} / \mathrm{ml})$ with perforin at $50-200 \mathrm{U} / \mathrm{ml}$. (B) Progressive changes in morphology and nuclear staining in response to perforin and FITC-grB. At $40 \mathrm{~min}$, the typical apeparance of adjacent apoptotic and non-apoptotic cells exposed to perforin and $\mathrm{grB}$ is shown under phase contrast microscopy (left), with the corresponding fluorescent confocal image shown at right. At 80 and $120 \mathrm{~min}$, other cells show progressive collapse and nuclear disintegration, with loss of nuclear definition. Control cells exposed to FITC-dextran and perforin are shown at $120 \mathrm{~min}$. Note that most of the FITC-grB remains extracellulr and the cell shape uniform 
We have previously observed nuclear and nucleolar accumulation of FITC-grB in semi-intact rat hepatoma cells (Trapani et al, 1996). However, in the present study, FITCgrB was not preferentially localized in the nucleolus. Cells exposed to the same quantity of FITC-grB in the absence of perforin were similar in appearance to the weakly-stained population exposed to both reagents. By 5-6 min, comparatively small amounts of FITC-grB were taken up into the cytoplasm, and extracellular fluorescence remained correspondingly higher than in cells additionally exposed to perforin (Figure 1A). Nuclear staining was not seen in cells exposed to FITC-grB alone, or in the population exposed to both agents that did not undergo apoptosis.

To exclude the possibility that entry of $\operatorname{grB}(32 \mathrm{kDa})$ might simply reflect cell membrane disruption due to perforin pore-formation, FDC-P1 cells were exposed to perforin in the presence of $20 \mathrm{kDa}$ FITC-dextran (Figure 1A, left panel and Table 1). The FITC-dextran was not taken up by cells, suggesting that entry of grB under these conditions was not due to 'non-specific' perforin-induced membranolysis. Indeed, cells exposed to FITC-dextran and unlabeled grB together with perforin were just as susceptible to apoptosis, but excluded FITC-dextran for up to 60 min (Table 1, and data not shown). We have made similar observations for cellular exclusion of $20 \mathrm{kDa}$ FITCdextran in the presence of perforin from HTC rat hepatoma cells (Jans et al, 1996) and mouse YAC-1 lymphoma cells ( $\mathrm{Fc} / \mathrm{Fmed}_{\max }=0.45$, unpublished observations). We also wished to determine whether the membrane lesions induced by perforin under these conditions were sufficiently large to permit the entry of molecules smaller than $20 \mathrm{kDa}$. We therefore examined the cytoplasmic and nuclear uptake of two inert proteins, the $13 \mathrm{kDa}$ subunit of a yeast cdk ( $\left.13^{\mathrm{suc}}\right)$ and bacterial azurin $(8 \mathrm{kDa})$ in the presence or absence of perforin and/or grB (Table 1). p13 suc showed no cytoplasmic accumulation when applied with perforin $(\mathrm{Fc} / \mathrm{Fmed}=0.28)$. An increase in this ratio was observed for azurin (from background levels, 0.36, up to 0.92), suggesting that the perforin lesions were just large enough to allow entry into the cell. Neither protein could

Table 1 Cellular and nuclear uptake of various molecules in FDC-P1 cells in the presence or absence of perforin and/or grB

\begin{tabular}{|c|c|c|c|}
\hline Molecule & Addition (s) ${ }^{1}$ & $(\text { Fc/Fmed })_{\max }{ }^{2}$ & $(\mathrm{Fn} / \mathrm{c})_{\max }{ }^{2}$ \\
\hline $\begin{array}{l}\text { FITC-grB } \\
\text { (32 kDa) }\end{array}$ & $\begin{array}{l}\text { None } \\
\text { Perforin }\end{array}$ & $\begin{array}{c}1.20 \\
2.72(1.40)^{3}\end{array}$ & $\begin{array}{c}0.83 \\
1.60(0.56)^{3}\end{array}$ \\
\hline $\begin{array}{l}\text { FITC-dextran grB } \\
\quad(20 \mathrm{kDa})\end{array}$ & $\begin{array}{l}\text { Perforin } \\
\text { Perforin+grB }\end{array}$ & $\begin{array}{c}0.76 \\
0.39 \\
0.98(0.51)^{3}\end{array}$ & $\begin{array}{l}0.73 \\
0.60 \\
N^{4}\end{array}$ \\
\hline $\begin{array}{l}\text { FLUOS-p13 } \\
\text { (13 kDa) }\end{array}$ & $\begin{array}{l}\text { None } \\
\text { Perforin } \\
\text { Perforin+grB }\end{array}$ & $\begin{array}{c}0.45 \\
0.28 \\
1.25(0.52)^{3}\end{array}$ & $\begin{array}{l}0.56 \\
0.73 \\
N^{4}\end{array}$ \\
\hline $\begin{array}{l}\text { FLUOS-azurin } \\
\qquad(8 \mathrm{kDa})\end{array}$ & $\begin{array}{l}\text { None } \\
\text { Perforin } \\
\text { Perforin+grB }\end{array}$ & $\begin{array}{c}0.36 \\
0.92 \\
1.12(0.65)^{3}\end{array}$ & $\begin{array}{l}0.84 \\
0.66 \\
N^{4}\end{array}$ \\
\hline
\end{tabular}

${ }^{1}$ Treatment with unlabeled protein. ${ }^{2}$ The data for maximal cellular $\left(\mathrm{Fc} / \mathrm{Fmed}_{\max }\right)$ or nuclear $\left(\mathrm{Fn} / \mathrm{c}_{\max }\right)$ accumulation represent the mean of least two separate experiments (S.E.M. $<12 \%$ of the mean). ${ }^{3}$ Values in parentheses indicate those for 'non-apoptotic' cells (see text). ${ }^{4}$ Not Determined inhibit apoptosis when applied with both perforin and unlabeled grB. Cell death under these conditions was associated with uptake of both $\mathrm{p} 13^{\mathrm{suc}}$ and azurin into the cytoplasm in the cells undergoing apoptosis (Fc/Fmed 1.25 and 1.12, respectively), but not in those that survived. These results indicated that the perforin lesions formed under these conditions were conducive to apoptosis, induced the redistribution of grB from the cytoplasm to the nucleus, yet did not permit the free passage of molecules as small as $13 \mathrm{kDa}$ into the cells. More precise definition of the size of the lesions effected by perforin will require examination of several other proteins in the 8$12 \mathrm{kDa}$ range, using the sorts of approaches described here.

\section{Nuclear uptake of FITC-grB in cell populations undergoing apoptosis}

FDC-P1 cells exposed to FITC-grB with or without perforin were observed under fluorescence microscopy, and simultaneously using CLSM in transmission mode to detect cells undergoing apoptosis (Figure 1B). After 25-40 min, only the cells with nuclear fluoresence (but none of the cells without nuclear fluorescence) began to show clear morphological evidence of apoptosis. These cells became highly refractile and the nuclei misshapen and irregular. Cell volume typically increased for a few minutes, and then contracted. When viewed under fluorescence, these nuclei initially became progressively brighter and condensed, but eventually disintegrated and their fluorescence became indistinguishable from cytoplasm (Figure 1B). By contrast, cells that excluded grB from the nucleus invariably remained alive. In the typical experiment shown (Figure 2A), very few apoptotic cells were seen in the first 25 min of exposure to perforin and FITC-grB. From that time onwards, the number of apoptotic cells continued to rise until the experiment ended at $4 \mathrm{~h}$. Apoptotic cells were also estimated by TUNEL staining and by binding of FITC-conjugated annexin V (Koopman et al, 1994) (data not shown). Both techniques confirmed that death was induced only when both perforin and grB were present, and numbers of dead cells by these criteria closely paralleled morphological observations. In the experiment shown, FDCP1 cells exposed to perforin and FITC-dextran (Figure 2A), or to perforin, FITC-grB or buffer alone (not shown) demonstrated fewer than $4 \%$ apoptotic cells throughout. CLSM in conjunction with image analysis was used to quantitate the subcellular uptake of FITC-grB. A time-course of nuclear accumulation of FITC-grB in the strongly stained and weakly stained cells exposed to perforin and FITC-grB is shown (Figure 2B). Only the cells undergoing apoptosis demonstrated significant nuclear accumulation of grB (Fn/c >1). In the typical experiment shown, nuclear acumulation of grB was very rapid: $\mathrm{Fn} / \mathrm{c}$ (fluorescence in the nucleus relative to that in the cytoplasm) reached maximal levels (1.60) at $7.5 \mathrm{~min}$ with a $_{1 / 2}$ of $\sim 2 \mathrm{~min}$. Fn/c did not exceed 0.5 in non-apoptotic cells. We have obtained very similar quantitative results using either HTC (Jans et al, 1996) or YAC-1 cells. In the latter case, the maximal $\mathrm{Fn} / \mathrm{c}$ values for $\mathrm{grB}$ in the absence and presence of perforin were 0.9 and 2.0, respectively (unpublished observations). 


\section{Kinetics of grB nuclear uptake}

In cells exposed to both FITC-grB and perforin for $10 \mathrm{~min}$, the brightly-staining population had taken up 2.5 to 3 times more grB into the cytoplasm than cells that did not undergo apoptosis (Figure 3 ). By $3 \mathrm{~h}$, this ratio had increased progressively to $\sim 5$. Initially, cells exposed to FITC-grB alone were very similar in appearance and fluorescence intensity with the non-apoptotic cells exposed to both reagents. Over the next $3 \mathrm{~h}$, however, cells exposed to grB alone progressively took up moderate quantities of FITC-grB, but did not undergo cell death. Accumulation in the nucleus only occurred in the population exposed to both perforin and grB that was undergoing (or about to undergo) apoptosis (Fn/c of about 1.5). Our results indicate clear differences in the cellular uptake and subcellular distribution of grB in apoptotic and non-apoptotic populations, both in the total amount taken up (Figure 3 ) and its subcellular distribution (Figure 2B).

\section{Nuclear entry of grB is not due to disruption of the nuclear envelope}

To confirm that in the experiments described above, grB was not entering the nucleus secondary to nuclear membrane damage, we added perforin and unlabeled grB to FDC-P1 cells whose cytoplasm was pre-loaded with FITC-labeled $70 \mathrm{kDa}$ dextran (Figure 4, left panel). The nuclei of these cells excluded the fluorescent label for up to $90 \mathrm{~min}(\mathrm{Fn} / \mathrm{c} \sim 0.5)$, irrespective of the presence of perforin and/or grB, implying that the nuclear envelope was intact even until late stages of apoptosis. Osmotic loading had not altered their sensitivity to grB in the presence of perforin, as mock-loaded cells exposed to FITC-grB and perforin rapidly accumulated grB in their nuclei, the $\mathrm{Fn} / \mathrm{c}$ reaching maximal levels ( $\mathrm{Fn} / \mathrm{c}$ of $1.8-2.0)$ in less than $45 \mathrm{~min}$ (Figure 4, right panel). Thus, grB entry into the nucleus did not result from non-specific nuclear membrane damage incurred during apoptosis, and as has been shown previously in other systems (Earnshaw, 1995; Casciola-Rosen et al, 1995), the nuclear envelope remained intact even until late in apoptosis.

\section{Kinetics of apoptosis-induced DNA fragmentation}

To more stringently ascertain if nuclear accumulation of grB preceded apoptosis, FDC-P1 cells were exposed to perforin and grB and the time course of DNA breakdown during apoptosis was examined by TUNEL (Figure 5). Since the incorporation of FITC-deoxyuridine into nicked DNA was measured, unlabeled grB was used in these studies. No DNA fragmentation above background levels ( $2 \%$ ) was seen
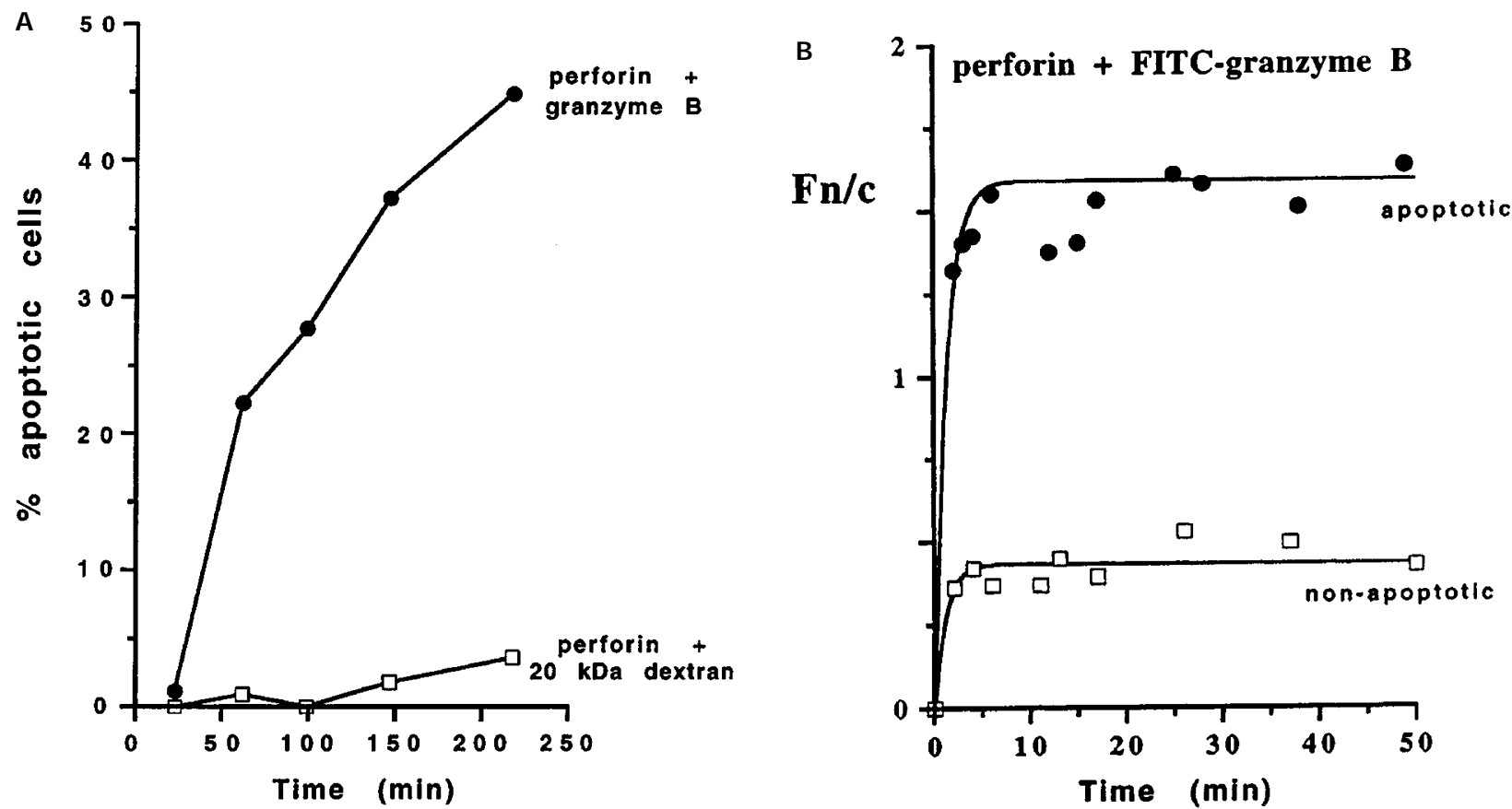

Figure 2 (A) Time course of apoptosis induced by grB and perforin. FCD-P1 cells were exposed to $100 \mathrm{U} / \mathrm{ml}$ perforin together with either FITC-dextran (20 kDa), or FITC-grB at $37^{\circ} \mathrm{C}$ as indicated. Cells with typical apoptotic morphology were enumerated visually ( 200 cells per time point). Background levels of apoptosis in cells exposed to perforin alone, FITC-grB alone or to buffer alone were $<4 \%$ in this experiment (not shown). The experiment depicted was typcial of ten similar experiments performed over a range of grB concentrations $(1-5 \mu \mathrm{g} / \mathrm{ml})$. (B) Kinetics of nuclear accumulation of FITC-grB in apoptotic and non-apoptotic FDC-P1 cells. Cells were treated as in A, mounted and examined using CLSM in fluorescence and phase-contrast modes. Image analysis was performed to quantitate cellular ( $\mathrm{Fc} /$ medium) and nuclear ( $\mathrm{Fn} / \mathrm{c}$ ) uptake (see Materials and Methods). Results represent at least six separate meeasurements for each of the fluorescence measurements (Fn, $\mathrm{Fc}$ and autofluorescence), with the S.E.M. less than $4.2 \%$ the value of the mean. Exponential curve fitting was performed as described previously $(27,28)$, with values for maximal nuclear uptake $\left(\mathrm{Fn} / \mathrm{c}_{\max }\right)$ being 1.59 and 0.43 for apoptotic and non-apoptotic cells respectively (regression coefficients of 0.91 and 0.94 for the curve fits, respectively). Maximal accumulation was achieved in the case of apoptotic cells within 7.5 min ( $t_{1 / 2} \sim 2$ min). Apoptotic and nonapoptotic cells were differentiated as described in the text 
after $10 \mathrm{~min}$ exposure to perforin and grB, but by $20 \mathrm{~min}$ approximately $32 \%$ of the cells had fragmented DNA (Figure 5). In further experiments (not shown), we determined that
DNA fragmentation was never observed prior to $13 \mathrm{~min}$, i.e. at least $11 \mathrm{~min}$ after grB was first observed in the nucleus (Figure 1). As expected, DNA fragmentation was not
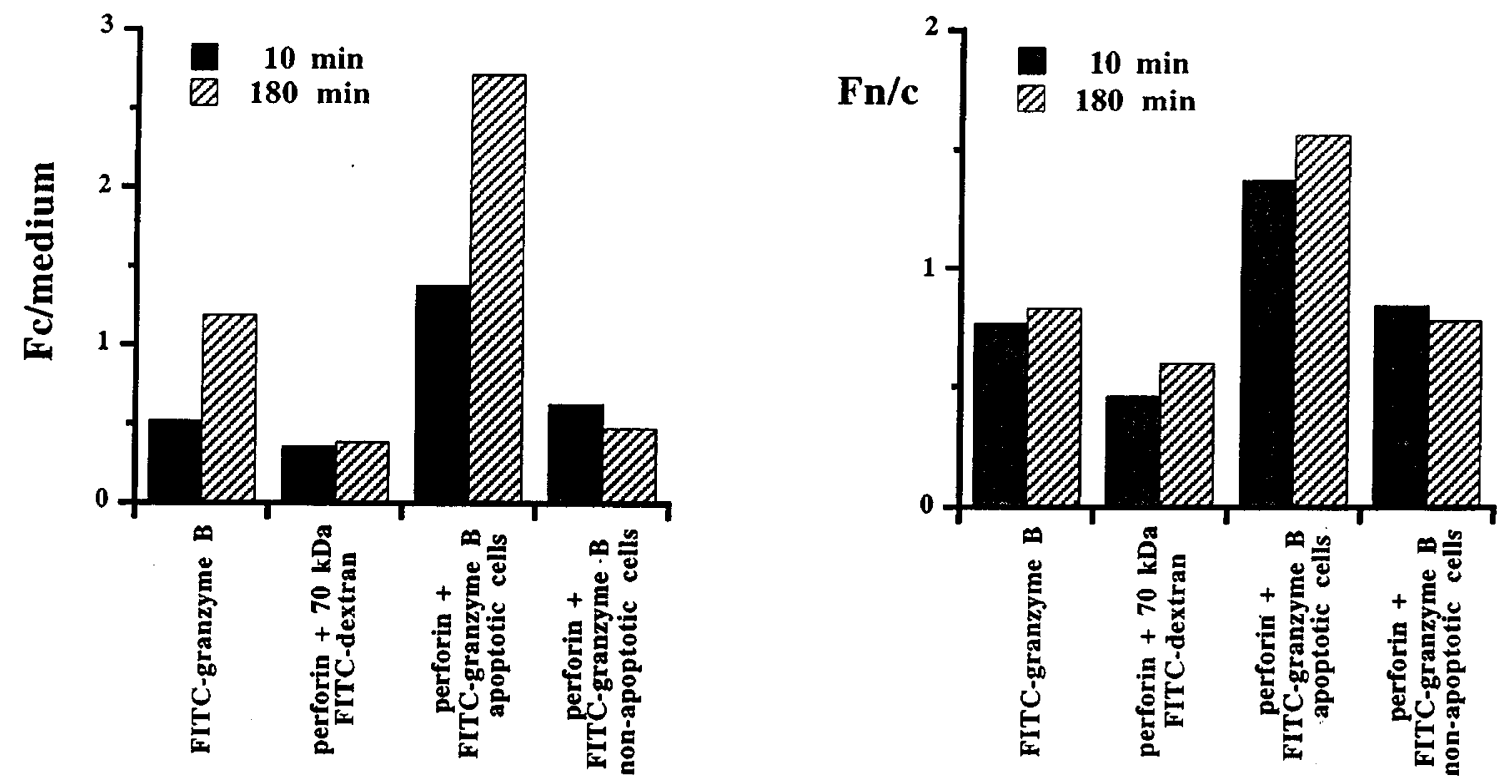

Figure 3 Cellular uptake and nuclear accumulation of FITC-grB by apoptotic and non-apoptotic FDC-P1 cells in the absence and presence of perforin. Cells were treated as described in the legend to Figure 1. Image analysis was performed to quantitate cellular ( $\mathrm{Fc} / \mathrm{medium})$ and nuclear (Fn/c) uptake. Results, shown for two time points for a single typical experiment, represent at least five separate measurements for each of the fluorescent measurements ( $F c$, Fmedium, Fn and autofluorescence), with the S.E.M. $<6.2 \%$ of the mean. Apoptotic and non-apoptotic cells were differentiated on the basis of morphological criteria (see text)
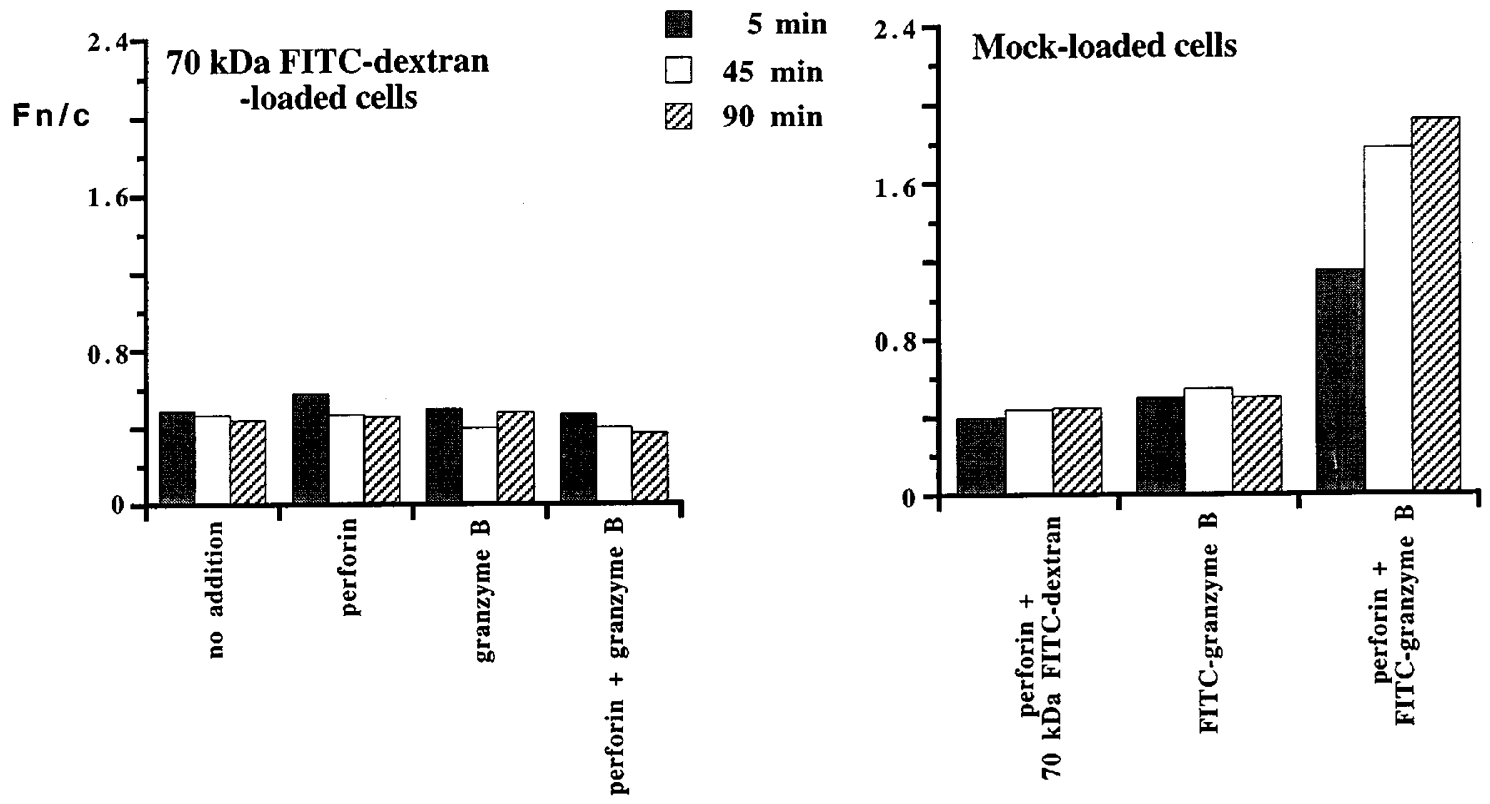

Figure 4 Nuclear membrane integrity in FDC-P1 cells in the presence of grB/perforin. Cells were cytoplasmically loaded with FITC-dextran (70 kDa) or mockloaded by hypertonic treatment as described (Nakajima and Henkart, 1994), prior to examination using CLSM and image analysis as described in the legend to Figure 3. Results, shown for three time points for a single typical experiment, represent at least four separate measurements for each of the fluorescent measurements ( $\mathrm{Fc}, \mathrm{Fn}$ and autofluorescence), with the S.E.M. $<9.9 \%$ of the mean. Cells pre-loaded with a $20 \mathrm{kDa}$ FITC-dextran in the same experiment yielded an $\mathrm{Fn} / \mathrm{C}$ of 1.01 (equal concentration in cytoplasm and nucleus) at $5 \mathrm{~min}$ (not shown) 
observed with either perforin or grB alone (Figure 5) or with $20 \mathrm{kDa}$ dextran and perforin (data not shown). The onset of DNA fragmentation therefore closely paralleled the appearance of apoptotic cells as described above (Figures 1 and 2). Overall, our results strongly suggest that grB accumulation in the nucleus preceded apoptosis, as defined by DNA breakdown or by morphological criteria.

\section{Discussion}

Several striking findings arose from the present study examining the intracellular distribution of grB in target cells exposed to perforin and grB as a model of CTL attack. We have clearly established by a variety of means that nuclear accumulation of grB preceded apoptosis, and was not simply a consequence of nuclear changes induced by apoptosis per se. In the presence of perforin, grB was very rapidly transported to the nucleus, with half-maximal levels achieved as rapidly as $2 \mathrm{~min}$, the shortest time in which cells could be imaged, and at least $11 \mathrm{~min}$ before single-stranded breaks could be detected in DNA. Significantly, by comparing the
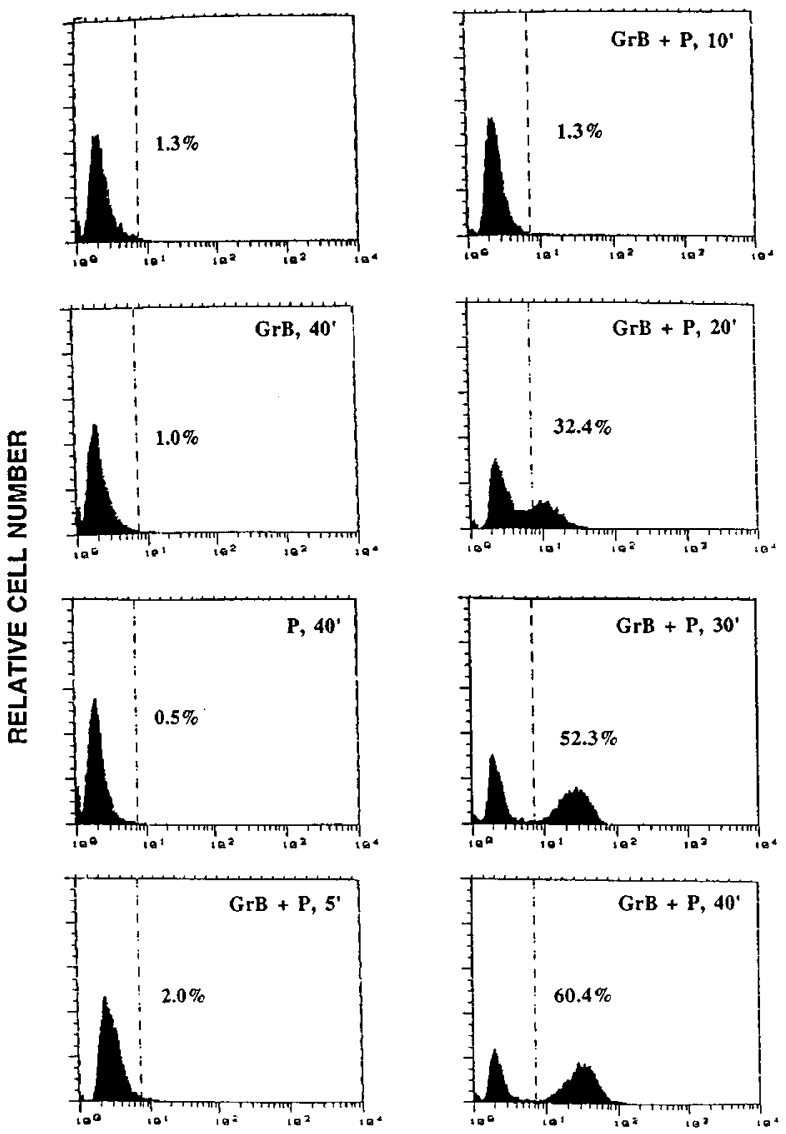

FLUORESCENCE INTENSITY

Figure 5 Time course of DNA fragmentation in response to grB and perforin using TUNEL. FDC-P1 cells were incubated in the presence of buffer alone, or with perforin $(P)$ and/or unlabeled grB for the times indicated at $37^{\circ} \mathrm{C}$. DNA fragmentation was assayed using TUNEL staining and cytofluorography. The percentages of cells with DNA fragmentation are indicated. The results shown are for a single typical experiment, from a series of three similar experiments simultaneous fluorescence and phase contrast appearances of many hundreds of cells, it was apparent that no cell that took up grB into its nucleus was spared from apoptosis. We have obtained very similar data using rat HTC or mouse Yac-1 cells (unpublished results), which indicates that our findings are not unique to FDC-P1 cells. The integrity of the nuclear membrane late in apoptosis was confirmed by our experiments in which the cytoplasm was loaded with $70 \mathrm{kDa}$ FITCdextran using the technique of Nakajima and Henkart (1994). Although some redistribution of nuclear pores occurs early in many forms of apoptosis (Earnshaw, 1995), the nuclear membrane usually remains impermeable to macromolecules until much later (Casciola-Rosen et al, 1995). Consistent with this, specifically degraded proteins, including PARP, remain intranuclear even after degeneration into discrete envelopeenclosed 'apoptotic bodies' (Casciola-Rosen et al, 1995). We have also shown previously that grB itself does not influence the passive permeability or active transport properties of the nuclear envelope (Trapani et al, 1996). Why only a subset of the FDC-P1 cells should be susceptible to perforin and grB is unclear. It now appears clear that cells are susceptible to the effects of grB and perforin throughout all stages of the cell cycle (Shi et al, 1996). We are currently examining possible parameters of resistance to apoptosis, including relative resistance to lysis by perforin, and differences in the uptake of grB.

It still remains to be determined whether granzymes (especially grB) contribute directly to intranuclear proteolysis in intact cells. We have unequivocally documented grB within the nucleus well before the classical nuclear changes of apoptosis take place, and this is consistent with grB contributing directly to nuclear damage. Nuclear proteins that can be cleaved by grB in vitro include PARP and DNA$P K c s$, and the preferred cleavage sites (asp residues) for grB on these molecules are distinct from those utilized by caspases (Song et al, 1996; Froelich et al, 1996a). In addition, grB has been shown to bind an undefined nucleoprotein of $85 \mathrm{kDa}$ (Pinkoski et al, 1996), while granzyme $A$, which can also be targeted to the nucleus of intact cells in the presence of perforin (unpublished observations) is capable of binding and cleaving the nuclear shuttle protein nucleolin (Pasternack et al, 1991). Therefore, granzymes may be directed to the nucleus to contribute to the proteolysis induced by caspases or their downstream effector molecules such as DFF (Liu et al, 1997).

We have shown here using FITC-tagged grB, and elsewhere using immuno-electron microscopy (Shi et al, 1997) that grB can be taken up into cells in the absence of perforin, pointing to the inadequacy of the hypothesis that polyperforin pores allow the passive diffusion of $\mathrm{grB}$ into the cell. However, the appearance of large amounts of grB in the cytoplasm and nuclei of cells undergoing apoptosis may be a consequence of, and a witness to the release of 'free' grB into the cytosol by perforin. It is likely that grB is taken up by intact cells in a vesicular form, and perforin may enable it to access the cytoplasm, perhaps by disrupting endocytic vesicles in a manner akin to adenovirus (Froelich et al, 1996b). This would allow grB to both activate the caspase cascade in the cytoplasm 
(thereby causing indirect nuclear damage by generating a battery of nucleolytic proteases), and to additionally target its own nuclear substrates directly. Furthermore, both we and others (Sarin et al, 1997) have recently shown that synthetic caspase inhibitors such as Z-VAD-fmk can abolish both the nuclear uptake of grB and nuclear apoptotic changes, indicating that an intact caspase cascade in mandatory for the nucleolytic effect of grB (unpublished observations).

Our findings clearly indicate that perforin can facilitate nuclear trafficking of grB in the case of CTL-mediated cell death; the intriguing possibility that it may do the same for endogenous proteases such as activated caspases is currently under investigation. There is abundant evidence that many structural and enzymatic nuclear proteins are cleaved during apoptosis (Kumar and Lavin, 1996), and the proteases that target these molecules are not constitutively in the nucleus, so at least some must be transported to their sites of action, presumably through nuclear pore complexes. Although the primary structure of perforin has been known for many years (Shinkai et al, 1988; Lichtenheld et al, 1988), the nature of the membrane signal delivered by perforin also remains elusive: the uptake of grB into the cell is clearly not explicable in terms of the formation of non-selective transmembrane pores, and there is no clear evidence for activation of generic membrane signaling pathways by perforin. The mechanism by which grB traverses the cell membrane in either the absence or presence of perforin is also unknown. In the present study, the addition of perforin increased the overall uptake of grB into the cell (2-3-fold that in its absence). Our observations are consistent with those of Shi et al (1992) who demonstrated that DNA fragmentation could proceed in the presence of minute (sublytic) quantities of perforin, provided the perforin signal was accompanied by grB. There is no evidence for a specific perforin receptor other than lipid molecules with phosphorylcholine headgroups (Tschopp et al, 1989), nor is is clear how perforin might influence the overall uptake of grB into the cell. Although we can reconstitute nuclear import of grB in semi-intact cells using cytosolic extracts (Trapani et al, 1996; Jans et al, 1996), we have been unable to reconstitute the apoptotic signal of perforin with other membrane disruptive agents including complement, calcium ionophores, phorbol esters or mild detergent treatment (Shi et al, 1997 and unpublished data). The key to unraveling the precise function/s of perforin clearly awaits the development of systems to study structure/function relationshisp for the various domains of this intriguing molecule.

\section{Materials and Methods}

\section{Cells}

Mouse FCD-P1 myeloid cells were cultured in DMEM supplemented with $10 \%$ fetal calf serum and recombinant IL-3-containing culture supernatant (Karasuyama and Melchers, 1988).

\section{Protein purification and labeling}

Immunoaffinity purified human grB was free of other granzymes and perforin as demonstrated previously (Trapani et al, 1993). GrB was labeled with FITC (Molecular Probes) as described (Trapani et al, 1996). This resulted in a $<20 \%$ reduction in cleavage of the synthetic tripeptide substrate Boc-ala-ala-asp-S-benzyl (Trapani et al, 1996). FITC grB was equally active as unlabeled grB, in ${ }^{51} \mathrm{Cr}$ release assays in the presence of perforin. Protein concentrations of grB were determined using the theoretical extinction coefficient of 1.20 (Gill and von Hippel, 1989). Microtiter assays for grB activity were as described (Trapani et al, 1994). Rat perforin was purified as described (Froelich et al, 1996b). The cdk subunit $p 13^{\text {suc }}$ was expressed in $E$. coli strain BL21(DE3)pLysS and purified essentially as described (Labbe et al, 1991). p13 ${ }^{\text {suc }}$ was labeled using FLUOS (Boehringer Mannheim), $150 \mu \mathrm{g}$ of which was dissolved in $450 \mu \mathrm{l}$ of DMSO and mixed with $2 \mathrm{mg}$ of $\mathrm{p} 13^{\text {suc }}$ dissolved in $1 \mathrm{ml}$ of $0.1 \mathrm{M}$ sodium bicarbonate, $\mathrm{pH}$ 8.5. After $90 \mathrm{~min}$ at room temperature, unbound dye was removed from the labeled protein by chromatography on Sephadex G25.

\section{Cellular uptake and distribution of fluoresceinated molecules}

FDC-P1 cells (Vaux et al, 1992) were harvested in the logarithmic phase of growth, washed three times and resuspended $\left(4 \times 10^{6} / \mathrm{ml}\right)$ in Hank's buffered saline solution containing $10 \mathrm{mM}$ Hepes $\mathrm{pH} 7.2,2 \mathrm{mM} \mathrm{CaCl}_{2}$, $0.4 \% \mathrm{BSA}$ and $0.1 \%(\mathrm{v} / \mathrm{v})$ IL-3-containing culture supernatant (Buffer A) (Shi et al, 1992). Cells $(6 \mu l)$ were incubated for the specified times with an equal volume of perforin (100-1000 U/ml, final concentration) and/ or FITC-grB $(0.25-10 \mu \mathrm{g} / \mathrm{ml}$, final concentration), or with an equivalent amount of unlabeled grB. Perforin and grB were diluted and mixed immediately before the assay in $10 \mathrm{mM}$ Hepes, $150 \mathrm{mM} \mathrm{NaCl}, 1 \mathrm{mM}$ EGTA, pH 7.2. The reaction mixture was immediately pipetted onto a glass slide as described (Trapani et al, 1996). The dose of perforin produced $<5 \%$ specific release of ${ }^{51} \mathrm{Cr}$ from FDC-P1 cells. In some experiments, FITC-labeled $20 \mathrm{kDa}$ dextran (Sigma), p13 ${ }^{\text {suc }}$ or azurin were added with perforin. FITC-dextran addition had no inhibitory effect on perforin-induced ${ }^{51} \mathrm{Cr}$ release from FDC-P1 (data not shown).

Cells were scored as non-apoptotic or apoptotic based on microscopic examination (see Results section). The validity of this approach was confirmed by TUNEL analysis (compare Figures $2 \mathrm{~A}$ and 5 ), and propidium iodide staining and electron microscopy (data not shown). Visualization and quantitation of the cellular and nuclear uptake of FITC-grB and the other FITC-labeled compounds was carried out using CLSM as described previously (Jans et al, 1991; Walaschewski et al, 1995; Xiao et al, 1996), and in particular for FITClabeled grB (Trapani et al, 1996; Jans et al, 1996). Image analysis and curve fitting was carried out as described (Trapani et al, 1996; Ymer and Jans, 1995). Results were expressed in terms of Fc/medium (cellular uptake parameter; fluorescence quantitated in the cytoplasm-Fc-relative to fluorescence quantitated in the mediumFmedium - following subtraction of background fluorescence), and Fn/ c (nuclear accumulation; fluorescence quantitated in the nucleus$\mathrm{Fn}$-relative to Fc, following subtraction of background fluorescence) (Trapani et al, 1996; Ymer and Jans, 1995). In some experiments, CLSM was performed using a transmission detector in order to provide phase contrast and fluorescent images of the same fields.

\section{Cytoplasmic loading of FDC-P1 cells with FITC-dextran}

Cells were washed twice and resupended in $0.1 \mathrm{ml}$ of hypertonic solution (0.5 M sucrose, 10\% polyethylene glycol 1000, $20 \mathrm{mM}$ Hepes, 
$\mathrm{pH}$ 7.2) (Nakajima and Henkart, 1994) containing $10 \mathrm{mg} / \mathrm{ml}$ FITClabeled 20 or $70 \mathrm{kDa}$ dextran at $37^{\circ} \mathrm{C}$ for $10 \mathrm{~min}$. The medium was then made hypotonic by adding $7.9 \mathrm{ml}$ of $60 \%$ RPMI medium diluted in water. Following a further $10 \mathrm{~min}$, the cells were washed twice in Buffer $A$ and resuspended at $4 \times 10^{6} / \mathrm{ml}$. Mock-loaded cells were incubated in hypertonic buffer lacking FITC-dextran.

\section{TUNEL assay}

Cells undergoing DNA fragmentation were enumerated with a TUNEL (terminal deoxyribonucleotidyl transferase labeling of DNA strand breaks with dUTP) kit purchased from Boehringer-Mannheim (Sydney, Australia), used according to the manufacturer's instructions. Cells were analyzed immediately on a cytofluorograph (FACScan, BectonDickinson).

\section{Acknowledgements}

This study was supported by a Project Grant from the National Health and Medical Research Council of Australia (JAT), a Wellcome Trust Senior Research Fellowship (MJS), and a grant from the Clive and Vera Ramaciotti Foundation (DAJ). We thank Lyndall Briggs, Lisa McDonald and Kylie Browne for technical assistance.

\section{References}

Boldin MP, Goncharov TM, Golstev YV and Wallach D (1996) Involvement of MACH, a novel MORT1/FADD-interacting protease, in Fas/APO-1- and TNF receptormediated cell death. Cell 85: 803-815

Boldin MP, Varfolomeev EE, Pancer Z, Mett IL, Camonis JH and Wallach D (1995) A novel protein that interacts with the death domain of fas/apo1 contains a sequence motif related to the death domain. J. Biol. Chem. 270: $7795-7798$

Casciola-Rosen LA, Anhalt GJ and Rosen A (1995) Specific cleavage of the $70 \mathrm{kdal}$ component of the U1 small nuclear ribonucleoprotein is a characteristic biochemical feature of apoptotic cell death. J. Exp. Med. 182: 1625-1634

Darmon AJ, Nicholson DW and Bleackley RC (1995) Activation of the apoptotic protease CPP32 by cytotoxic T-cell-derived granzyme B. Nature 377: 446-448

Darmon AJ, Ley TJ, Nicholson DW and Bleackley RC (1996) Cleavage of CPP32 by grazyme $B$ represents a critical role for granzyme $B$ in the induction of target cell DNA fragmentation. J. Biol. Chem. 271: 21709-21712

Duke RC, Persechini PM, Chang S, Liu C-C, Cohen JJ and Young JD-E (1989) Purified perforin induces target cell lysis but not DNA fragmentation. J. Exp. Med. 170: $1451-1456$

Earnshaw WC (1995) Nuclear changes in apoptosis. Curr. Opin. Cell Biol. 7: $337-$ 343

Fernandes-Alnemri T, Armstrong R, Krebs J, Srinivasula SM, Wang L, Bullrich F, Fritz L, Tomaselli KJ, Trapani JA, Croce C, Litwack G and Alnemri ES (1996) Activation of CPP32 and Mch3 by Mch4, a novel human apoptotic cysteine protease containing two FADD-like domains. Proc. Natl. Acad. Sci. USA 93: $7464-7469$

Froelich CJ, Hanna WL, Poirier GG, Duriez PJ, D'Amours D, Salvesan GS, Alnemri ES, Earnshaw WC and Shah GM (1996a) Granzyme B/perforin mediated apoptosis of Jurkat cell results in cleavage of ploy(ADPribose) polymerase to the $89 \mathrm{kDa}$ apoptotic fragment and a less abundant $64 \mathrm{kDa}$ fragment. Biochem. Biophy. Res. Commun. 227: 658-667

Froelich CJ, Orth K, Turbov J, Seth P, Gottlieb R, Babior B, Shah GM, Bleackley RC, Dixit VM and Hanna W (1996b) New paradigm for lymphocyte granule mediated cytotoxicity: target cells bind and internalize granzyme $B$ but an endosomolytic agent is necessary for cytosolic delivery and subsequent apoptosis. J. Biol. Chem. 271: 29073-29079

Gill SC and von Hippel PM (1989) Calculation of protein extinction coefficients from amino acid sequence data. Analytical Biochem. 182: 319-326

Heusel JW, Wesselschmidt RL, Shresta S, Russell JH and Ley TJ (1994) Cytotoxic lymphocytes rquire granzyme $B$ for the rapid induction of DNA fragmentation and apoptosis in allogeneic target cells. Cell 76: 977-987
Jans DA, Ackermann M, Bischoff JR, Beach DH and Peters R (1991) p34 cdc2. mediated phosphorylation at $\mathrm{T}^{124}$ inhibits nuclear import of SV40 T-antigen proteins. J. Cell Biol. 115: 1203-1212

Jans DA, Jans P, Briggs LJ, Sutton V and Trapani JA (1996) Reconstitution of nuclear and nucleolar transport of the natural killer cell serine protease grazyme Bdependence on perforin in vivo and cytosolic factors in vitro. J. Biol. Chem. 271: 30781-30789

Kagi D, Ledermann B, Burki K, Seiler P, Odermatt B, Olsen KJ, Podack ER, Zinkernagel RM and Hengartner $\mathrm{H}$ (1994) Cytotoxicity mediated by $\mathrm{T}$ cells and natural killer cells is greatly impaired in perforin-deficient mice. Nature 369:3135

Kaufmann SH, Desnoyers S, Ottaviano M, Davidson NE and Poirier GG (1993) Specific proteolytic cleavage of poly (ADP-ribose) polymerase: an early marker of chemotherapy-induced apoptosis. Cancer Res., 53: 39763985

Karasuyama $\mathrm{H}$ and Melchers $\mathrm{F}$ (1988) Establishment of mouse cell lines which constitutvely secrete large quantities of interleukin $2,3,4$ or 5 , using modified cDNA expression vectors. Eur. J. Immunol. 18: 97-102

Koopman G, Reutelinsperger CP, Kuitjen GA, Keehnan RM, Pals ST and van Oers MH (1994) Annexin V for flow cytometric detection of phosphatidylserine expression on B cells undergoing apoptosis. Blood 84: 1415-1420

Kumar S and Lavin MF (1996) The ICE family of cysteine proteases as effectors of cell death. Cell Death Differ. 3: 255-267

Labbe J-C, Cavadore J-C and Doree M (1991) M-phase specific cdc2 kinase preparation from starfish oocytes and properties. Methods Enzymol. 200: 291301

Lazebnik YA, Kaufmann SH, Desnoyers S, Poirier GG and Earnshaw WC (1994) Cleavage of poly (ADP-ribose) polymerase by a proteinase with properties like ICE. Nature 371: $346-347$

Lichtenheld MG, Olsen KJ, Lu P etal (1988) Structure and function of human perforin. Nature 335: 448-451

Lowin B, Beermann F, Schmidt A and Tschopp J (1994) A null mutation in the perforin gene impairs cytolytic T lymphocyte- and natural killer cell-mediated cytotoxicity. Proc. Natl. Acad. Sci. USA 91: 11571-11575

Liu X, Zou H, Slaughter C and Wang X (1997) DFF, a heterodimeric protein that functions downstream of caspase-3 to trigger DNA fragmentation during apoptosis. Cell 89: 175-184

Nakajima H and Henkart PA (1994) Cytotoxic lymphocytes trigger a target cell disintegration pathway leading to cytolysis and DNA breakdown. J. Immunol. 152: $1057-1063$

Nicholson DW, Ali A, Thornberry NA, VillaincourtJP, Ding CK, Gallant M, Garaeau Y, Griffin PR, Labelle M, Lazebnik YA, Munday NA, Raju SM, Smulson ME, Yamin TT, Yu VL and Miller DK (1995) Identification and inhibition of the ICE-CED-3 protease necessary for mammalian apoptosis. Nature 376: 37-43

Ortaldo JR, Winkler-Pickett RT, Nagashima K, Yagita Hand Okumura K (1992) Direct evidence for release of pore-forming protein during NK cellular lysis. J. Leukoc. Biol. 52: $483-488$

Pasternack MS, Bleier KJ and McInerney TN (1991) Granzyme A binding to targetcell proteins. Granzyme A binds to and cleaves nucleolin in vitro. J. Biol. Chem. 266: $14703-14708$

Pinkoski MJ, Winkler U, Hudig D and Bleackley RC (1996) Binding of granzyme B in the nucleus of targetcells. Recognition of the 80 kilodalton protein. J. Biol. Chem. 271: $10225-10229$

Poe M, Blake JT, Boulton DA, Gammon N, Sigal NH, Wu JK and Zweernik HJ (1991) Human cytotoxic lymphocyte granzyme $B$ : its purification from granules and the characterization of substrate and inhibitor specificity. J. Biol. Chem. 266: $98-$ 103

Quan LT, Tewari M, O'Rourke K, Dixit V, Snipas SJ, Poirier GG, Ray C, Pickup DJ and Salvesan GS (1996). Proteolytic activation of the cell death protease Yama/ CPP32 by granzyme B. Proc. Natl. Acad. Sci. USA 93: 1972-1976

Rouvier E, Luciani MF and Golstein P (1993) Fas involvement in $\mathrm{Ca}^{2+}{ }^{2+}$ independent $\mathrm{T}$ cell-mediated cytotoxicity. J. Exp. Med. 177: 195-200

Sarin A, Williams MS, Alexander-Miller MA, Berzofsky JA, Zacharchuk CM and Henkart PA (1997) Target cell lysis by CTL granule exocytosis is independent of ICE/Ced-3 family proteases. Immunity 6: 209-215

Shi L, Chen G, He D, Bosc DG, Litchfield DW and Greenberg AH (1996) Granzyme B induces apoptosis and cyclin A-associated cyclin-dependent kinase (cdk) activity in all stages of the cell cycle. J. Immunol. 157: 2381-2385 
Shi L, Kraut RP, Aebersold R and Greenberg AG (1992) A natural killer cell granule protein that induces DNA fragmentation and apoptosis. J. Exp. Med. 175: 553565

Shi L, Mai S, Israels S, Browne K, Trapani JA and Greenberg AH (1997) Granzyme B (GraB) autonomously crosses the cell membrane and perforin initiates apoptosis and GraB nuclear localization. J. Exp. Med. 185: 855866

Shinkai Y, Takio K and Okumura K (1988) Homology of perforin to the ninth component of complement (C9). Nature 334: 525-527.

Smyth MJ and Trapani JA (1995) Granzymes: exogenous proteinases that induce target cell apoptosis. Immunol. Today 19: 202-206

Song Q, Burrows S, Lees-Miller S, Smith G, Jackson S, Kumar S, Trapani JA, Alnemri E, Litwack G, Lu H, Moss D and Lavin M (1996) ICE-like protease cleaves DNA-dependent protein kinase in cytotoxic T-cell killing. J. Exp. Med. 184: 619-628

Srinivasula S, Fernandes-Alnemri T, Zangrilli J, Robertson N, Armstrong RC, Wang L, Trapani JA, Tomaselli KJ, Litwack G and Alnemri ES. (1996) J. Biol. Chem. 271: $27099-27106$

Tewari M, Quan LT, O'Rourke K, Desnoyers S, Zens Z, Beidler DR, Poirier GG, Salvesan GS and Dixit V (1995) Yama/CPP32b, a mammalian homologue of CED-3, is a crmA-inhibitable protease that cleaves the death substrate poly(ADP-ribose) polymerase. Cell 81: 801-809

Trapani JA, Browne KA, Smyth MJ and Jans DA (1996) Localization of granzyme B in the nucleus: a putative role in the mechanism of cytotoxic lymphocyte-mediated apoptosis. J. Biol. Chem. 271: 4127-4133

Trapani JA, Browne KA, Dawson M and Smyth MJ (1993) Purification of functional asp-ase (natural killer granzyme B) using a monoclonal antibody. Biochem. Biophys. Research Commun. 158: 910-920
Trapani JA, Smyth MJ, Apostolidis VA, Dawson M and Browne KA (1994) Granule serine proteases are normal nuclear constituents of natural killer cells. J. Biol. Chem. 269: 18359-18365

Trauth BC, Klas C, Peters AM, Matzku S, Molelr P, FalkW, Debatin KM and Krammer $\mathrm{PH}$ (1989) Monoclonal antibody-mediated tumor regression by induction of apoptosis. Science 245, 301-305

Tschopp J, Schafer S, Masson D, Peitsch MC and Heusser C (1989) Phosphorylcholine acts as a $\mathrm{Ca}^{2+}$-dependent receptor molecule for lymphocyte perforin. Nature 337: 272-274

Vaux DL, Aguila HL and Weissman IL (1992) Bcl-2 prevents death of factor deprived cells but fails to prevent apoptosis in targets of cell mediated killing. Int. Immunol. 4: $821-827$

Walaschewski U, Jans DA, Neugebauer-Goedde D-C and Peters R (1995) Semiintactcells for nucleo-cytoplasmic transportstudies. Methods in Mol. Cell. Biol.5: $87-95$

Xiao C-Y, Hübner S, Elliot RM, Caon M and Jans DA (1996) A consensus PK-A site in place of the CcN motif casein kinase ll site of SV40 large T-antigen confers PK-Amediated regulation of nuclear import. J. Biol. Chem. 271: 6451-6457

Ymer S and Jans DA (1995) In vitro Chromatin structure of the murine interleukin-5 gene region: a new intact cell system (1996) Biotechniques 20: 834-840

Yonehara S, Ishii A and Yonehara K (1989) A cell killing monoclonal antibody (ANTIFas) to a cell surface antigen co-downregulated with the receptor for tumor necrosis factor. J. Exp. Med. 169: 1747-1756

Young JD-E and Cohn ZA (1986) Cell-mediated killing: a common mechanism? Cell 46: $641-648$ 